\title{
Article/Artigo
}

\section{Drug resistance of Mycobacterium tuberculosis strains in Southern Brazil}

\author{
Estudo da resistência de cepas de Mycobacterium tuberculosis aos antimicrobianos no Sul do Brasil
}

\author{
Laynara Katize Grutzmacher ${ }^{1}$, Eduardo Monguilhott Dalmarco ${ }^{2}$, Solange Lucia Blatt ${ }^{1}$ and Caio Mauricio \\ Mendes de Cordova ${ }^{1}$
}

\begin{abstract}
Introduction: The aim of this work was to evaluate the prevalence of Mycobacterium tuberculosis (MT) strains with mutations that could result in resistance to the main drugs used in treatment in a region with one of the highest numbers of tuberculosis (TB) cases in southern Brazil. Methods: Deoxyribonucleic acid (DNA) from 120 sputum samples from different patients suspicious of pulmonary tuberculosis who attended the Municipal Public Laboratory for Mycobacterium sp. diagnosis was directly amplified and analyzed by PCR-SSCP. The DNA was amplified in known hotspot mutation regions of the genes $r p o B$, ahpC, embB, kat $G$, inh $A$, and pncA. Results: The percentage of samples positive by culture was $9.2 \%(11 / 120) ; 5 \%(6 / 120)$ were positive by bacilloscopy and MT-PCR, and DNA fragments of the aforementioned resistance genes could be amplified from seven (7) of the eleven (11) samples with positive results, either by culture or PCR/bacilloscopy. All presented a SSCP pattern similar to a native, nonresistant genotype, with the ATCC strain 25177 as control, except for one sample (0.01\%), which presented a SSCP profile demonstrating mutation at the embB gene. Conclusions: These results are consistent with the empirical observations by physicians treating $\mathrm{TB}$ patients in our region of a low occurrence of cases that are refractory to conventional treatment schemes, in contrast to other parts of the country. Continued surveillance, especially molecular, is essential to detect and monitor the outbreak of MT-resistant strains.
\end{abstract}

Keywords: Antibiotic. Mycobacterium. PCR-SSCP. Resistance. Tuberculosis.

\section{RESUMO}

Introdução: $\mathrm{O}$ objetivo deste trabalho foi avaliar a prevalência de cepas de Mycobacterium tuberculosis (MT) com mutações que podem resultar em resistência às principais drogas utilizadas no tratamento em uma das regiões com o maior número de casos de tuberculose (TB) no Sul do Brasil. Métodos: O ácido desoxiribonucleico (DNA) de 120 amostras de escarro de diferentes pacientes com suspeita de TB pulmonar que procuraram o serviço público de saúde do município sede da região para o diagnóstico de MT foi diretamente amplificado e analisado por PCR-SSCP. Foram amplificadas regiões conhecidas onde ocorrem a maioria das mutações nos genes rpoB, ahpC, embB, kat $G$, inh $A$, and $p n c A$. Resultados: Nove virgula dois por cento $(11 / 120)$ das amostras apresentaram resultado positivo por cultura, $5 \%(6 / 120)$ foi positiva por bacilscopia e PCR para MT, e os fragmentos dos genes mencionados puderam ser amplificados em sete (7) dos onze (11) casos com resultado positivo, seja por cultura ou PCR/baciloscopia. Todos estes casos apresentaram um padrão de SSCP similar ao genótipo nativo, não resistente, por comparação com a cepa controle ATCC 25177, com exceção de uma amostra (0,01\%), que apresentou um padrão de SSCP mutante no gene embB. Conclusões: Estes resultados são consistentes com as observações empíricas por parte dos clínicos que tratam os pacientes com TB na região, de uma baixa ocorrência de casos refratários ao tratamento convencional, em contraste com outras partes do país. Porém, a vigilância contínua, especialmente molecular, é essencial para identificar e monitorar o aparecimento de cepas de MT resistentes.

Palavras-chaves: Antibióticos. Mycobacterium. PCR-SSCP. Resistência. Tuberculose.

1. Departamento de Ciências Farmacêuticas, Universidade de Blumenau. Blumenau-SC. 2. Departamento de Análises Clínicas, Centro de Ciências da Saúde, Universidade Federal de Santa Catarina, Florianópolis, SC. Address to: Dr. Caio Mauricio Mendes de Cordova. Depto de Ciências Farmacêuticas/FURB. Rua São Paulo 2171, Campus III, Itoupava Seca, 89030-000 Blumenau, SC, Brasil.

Phone: $55473321-7318$

e-mail: cmcordova@furb.br

Received in 08/03/2011

Accepted in 19/09/2011

\section{INTRODUCTION}

Because tuberculosis (TB) has deep social roots intimately linked to unequal income distribution, the problem with the disease reflects the level of development of a country. Causes related to poverty, the weak organization of health systems, and administration deficiencies limit technology implementation and, as a consequence, contribute to the dissemination of the etiological agent and the increase in population susceptibility. Since 1993, the World Health Organization (WHO) has considered TB a global emergency, thus supporting measures for its control ${ }^{1,2}$. However, the battle against the disease is far from over.

The region of the Itajaí Valley in the State of Santa Catarina, which has about 500,000 inhabitants, is among the regions with the highest number of TB cases in southern Brazil (source: http://portalses. saude.sc.gov.br).

Reports of Mycobacterium tuberculosis (MT) strains resistant to the antibiotics used in treatment have been noted everywhere in the world ${ }^{3}$. Besides empirical observations of the absence of resistant Mycobacterium strains in our region, reported by the physicians who treat the TB patients, it is obviously important to offer and perform active research to monitor an eventual rise in resistance using fast and efficient tools, such as molecular methods. As is well known, MT cultures may take up to 8 weeks to yield results, and in the case of positivity, antibiotic sensitivity testing by traditional microbiologic techniques takes about 4 weeks more. During this time, the patient may already be spreading MT-resistant strains to close contacts. Using methods capable of offering results in a couple of days allows physicians to be readily informed and to take the appropriate therapeutic measures on time. Based on empirical information about the observation, obtained from the Municipality Laboratory staff, the number of patients with more than one year of TB treatment still presenting positive bacilloscopy results may be significant.

In the State of Santa Catarina, as well as in most of the country, M. tuberculosis susceptibility testing is currently performed only at the Central Public 
Laboratory in the capital of each state by microbiologic methods. It is interesting to note that before 2009, the guidelines accepted by the public health system allowed requests for these tests only by patients with certain conditions, including HIV patients, symptomatic patients with negative bacilloscopy, and any patient who is not responsive to current therapy, among other special circumstances ${ }^{4}$. An immune competent patient eventually infected by a resistant MT strain had to wait for treatment failure and 8 more weeks on average for laboratorial evidence that could improve his outcome. Only after the implementation of new national guidelines, published in August 2009, has culture with antibiotic sensitivity testing for any respiratory symptomatic patient with suggestive radiographic findings been advised ${ }^{5}$. However, this is not the case observed in clinical practice, which continues to be based on bacilloscopy findings for primary diagnosis.

In this context, through the Clinical Laboratory of the University Ambulatory Center of our institution, which assists patients in the whole region as a reference service, we aimed to offer the possibility of detection of mutations that may lead to MT resistance to first-line oral antibiotics used for TB treatment in Brazil, through a molecular method such as polymerase chain reaction followed by single-strand conformational polymorphism (PCR-SSCP). This methodology is a robust, fast, and reliable technique that may allow a medical decision in up to a couple of days. Furthermore, to date, no updated information about the prevalence of Mycobacterium-resistant strains is available in our region. As a starting point, in this study we have evaluated the eventual presence and prevalence of resistant TB strains in our public health system (SUS) with the use of PCR-SSCP. These results may contribute to the evaluation of the current TB treatment scheme used in the system, as well as provide new information about the prevalence of resistant strains in our population. Such information is crucial for evaluating the management and surveillance policies on the tuberculosis control effort.

\section{METHODS}

\section{Patients and samples}

We analyzed 120 sputum samples from different patients suspicious of pulmonary tuberculosis who have attended the Municipal Public Laboratory for Mycobacterium sp. diagnosis. After processing for bacilloscopy at the site, the samples were sent to the Clinical Laboratory of the University Ambulatory of our institution for culture and PCR.

\section{Sample treatment}

The samples were treated by a conventional modified method using $1 \% \mathrm{NaOH}$, SDS, and phosphoric acid ${ }^{6}$. The treated samples were then used for culture and PCR. DNA was extracted and purified as described elsewhere ${ }^{7}$.

\section{Mycobacterium tuberculosis diagnosis}

Bacilloscopy was performed directly on sputum sample slides stained by the Ziehl-Neelsen method. The culture was prepared by inoculation of samples in Löwenstein-Jensen medium and incubation at $37^{\circ} \mathrm{C}$ for up to 8 weeks. For PCR, DNA was amplified with a primer pair specific to $M$. tuberculosis (MT1: 5'-CCT.GCG.AGC. GTA.GGC.GTC.GG-3' and MT2: 5'-CTC.GTC.CAG.CGC.CGC. TTC.GG $-3^{\prime}$ ), resulting in a $123 \mathrm{bp}$ fragment of the insertion element IS61 $10^{8}$. Positive samples obtained by any of the methodologies used for MT diagnosis were used in PCR-SSCP tests.

\section{Polymerase chain reaction}

For detection of MT strains harboring mutations that may lead to resistance to rifampicin, isoniazid, pyrazinamide, and ethambutol, we amplified hotspot sites at the genes $r p o B, k a t G$, inh $A, a h p C, p n c A$, and $e m b B$. The amplicons were later submitted to SSCP-PCR (singlestrand conformation polymorphism-polymerase chain reaction) ${ }^{9}$. The primers were synthesized according to the sequences described by others ${ }^{10}$. Amplification reactions were performed in a volume of $25 \mathrm{uL}$, consisting of $0.5 \mathrm{uL}$ of each $10 \mathrm{uM}$ primer (Invitrogen), $0.2 \mathrm{uL}$ of $100 \mathrm{uM} \mathrm{dNTPs}$ (Invitrogen), $1.0 \mathrm{uL}$ of $50 \mathrm{mM} \mathrm{MgCl}_{2}$ (Invitrogen), and $1.0 \mathrm{U}$ of Taq DNA polymerase in the provided reaction buffer (Invitrogen). The annealing temperatures were $64^{\circ} \mathrm{C}$ for the $r p o B$ and $e m b B, 57^{\circ} \mathrm{C}$ for the $p n c A$, and $55^{\circ} \mathrm{C}$ for the $a h p C, k a t G$, and inhA genes. As naïve control, purified DNA from the ATCC 25177 M. tuberculosis strain was amplified.

\section{Single-strand conformation polymorphism}

The PCR amplicons of the aforementioned gene hotspots were resolved by $1 \%$ agarose gel electrophoresis with ethidium bromide staining under UV light. Those samples with positive amplification were submitted to native $5.5 \%$ polyacrylamide gel electrophoresis after denaturation of the double-strand DNA. Briefly, $18 \mu \mathrm{L}$ of formamide dye mix was added to $2 \mu \mathrm{L}$ of each PCR product, followed by boiling for $5 \mathrm{~min}$ and immediate cooling on ice; $2 \mu \mathrm{l}$ of $10 \mathrm{x}$ sucrose gel loading buffer was added, after which the mixture was applied to the gel and submitted to $300 \mathrm{~V}(45 \mathrm{~mA})$ for $5 \mathrm{~h}$. The gel was stained with $\mathrm{AgNO}_{3}$ and photographed ${ }^{11}$.

\section{Ethical considerations}

This project was approved by the Committee on Ethics in Research with Human Beings of our institution (Protocol no. 032/03) under the guidelines of the Helsinki Declaration of 1964 and further revisions.

\section{RESULTS}

Among the 120 patient samples tested for MT diagnosis, six (5\%) were positive either by bacilloscopy or PCR with primers specific to the M. tuberculosis IS6110 element. On the other hand, eleven (9.2\%) were positive by culture.

The samples that were positive by either method were tested by PCR-SSCP for detection of mutations in the hotspot regions of the genes responsible for the phenotypes resistant to the main antibiotics used in treatment.

The $399 \mathrm{bp}$ fragment of the $e m b B$ gene related to ethambutol resistance could be amplified from five (5) positive samples (Figure 1A). Regarding resistance to isoniazide, the $457 \mathrm{bp}$ fragment of the inh $A$ gene, the $703 \mathrm{bp}$ fragment of the $k a t G$ gene, and the $587 \mathrm{bp}$ product of the $a h p C$ gene could also be equally amplified from five (5) samples (Figure 1B).

Regarding resistance to rifampicin, the $349 \mathrm{bp}$ fragment of the $r p o B$ gene could be amplified from ten (10) samples (Figure 1C).

The 940bp hotspot fragment of the gene responsible for pyrazinamide resistance, $p n c A$, could be amplified from five (5) positive samples (Figure 1D).

Except for one sample, which presented a SSCP profile demonstrating mutation in the $e m b B$ gene and that could lead to an 


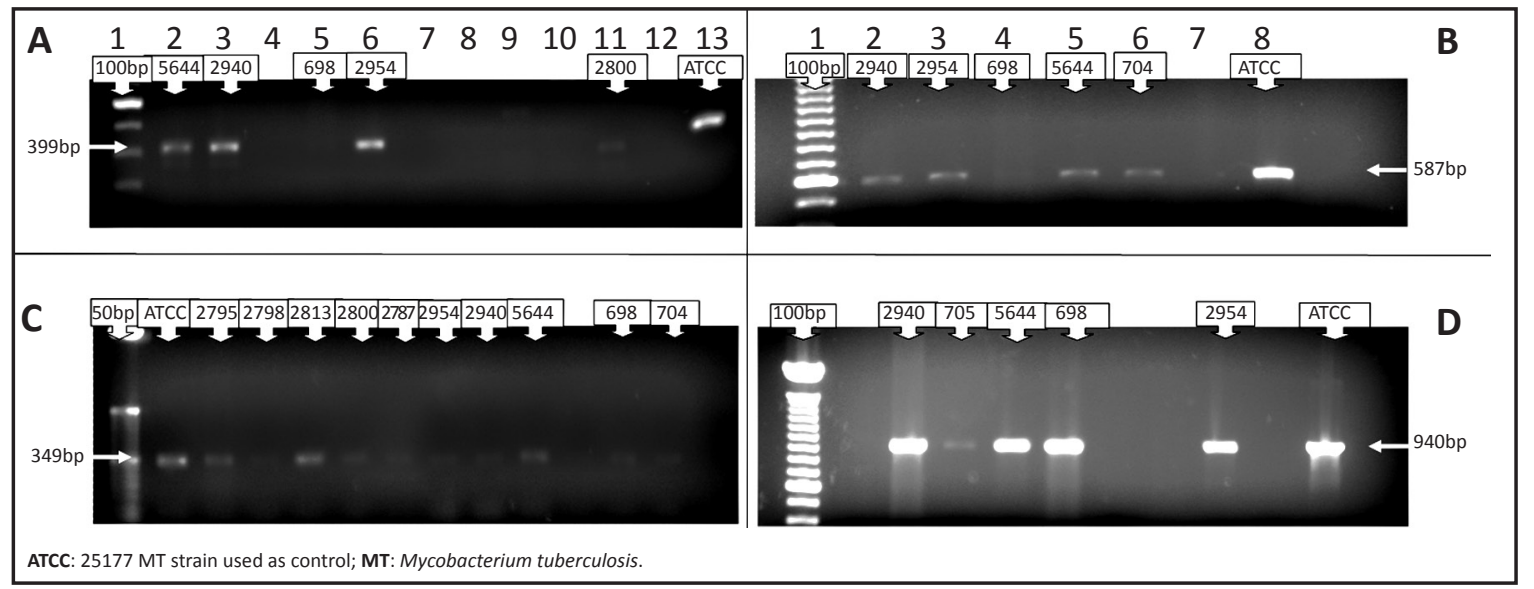

FIGURE 1 - Polymerase chain reaction amplification of hotspot mutation regions of the genes embB (A), ahpC (B), rpoB (C), and pncA

(D), from samples with a positive result for MT diagnosis, either by culture, IS6110 PCR, or bacilloscopy.

ethambutol resistant phenotype (Figure 2), all the samples from which it was possible to amplify a hotspot fragment of the genes responsible for $M$. tuberculosis resistance evaluated in this study presented a SSCP pattern similar to a native, nonresistant genotype, using the ATCC strain 25177 as control.
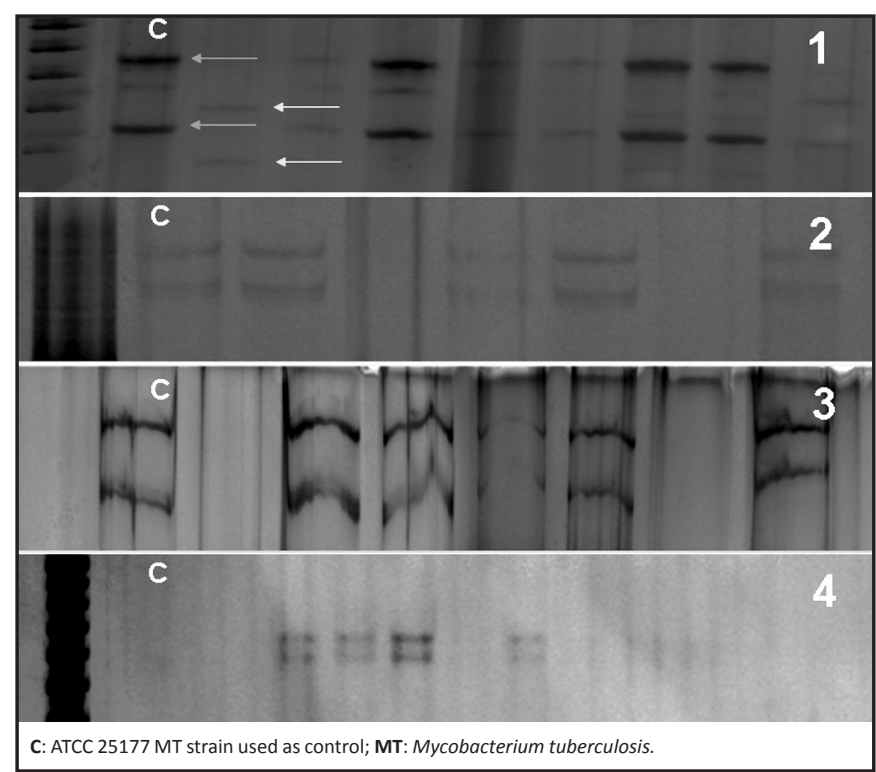

FIGURE 2 - Single-strand conformation polymorphism of polymerase chain reaction amplicons from the genes embB (1), $\operatorname{hhpC}(2), r p o B(3)$, and $p n c A$ (4), from samples with a positive result for MT diagnosis, either by culture, IS6110 PCR, or bacilloscopy.

\section{DISCUSSION}

Estimates from the WHO indicate that nearly one third of the world's population is infected by the TB bacilli. About 8.8 million new cases are recorded every year, with 1.6 million deaths. Twentytwo countries harbor about $80 \%$ of all cases in the world, and Brazil occupies the $16^{\text {th }}$ position in this ranking, with $70 \%$ of the cases concentrated in 315 of its 5,570 cities $^{12-14}$. Strategies to stop the advance of this epidemic, however, are threatened not only by its synergic effect with HIV/AIDS but mainly by the increasing number of multiresistant strains. With the risk of the wide spread of resistant bacilli, the lack of stringent control and monitoring of patients may exponentially increase the rise of resistance, a drawback in the efforts on tuberculosis control ${ }^{15,16}$.
A few reports point out a decrease in multiresistant TB cases in the last decade; however, most studies indicate the opposite. A study conducted in Brazil from 1996 to 1997 reported that 31\% of analyzed strains were resistant to the main drugs used in treatment. M. tuberculosis presents a significant frequency of naturally resistant mutants: 1:106 for isoniazide, 1:108 for rifampicin, but less than 1:1014 for both simultaneously. Misuse of the drugs certainly contributes to the selection of resistant strains ${ }^{13,17}$.

There are four known mechanisms through which bacterial resistance is acquired (conjugation, transformation, transduction, and mutation), but it is mainly by mutation that $M$. tuberculosis becomes resistant to drugs. Genetic and molecular analyses of resistant bacilli also suggest that resistance is acquired by mutations in the genes that codify the drug target. Unlike many other bacteria, MT does not perform horizontal gene transfer. The mechanism of multidrug resistance is still uncertain as no single gene involved has been identified; rather, it has been observed that multiresistant phenotypes arise from mutation in different genes ${ }^{18}$.

Rifampicin binds to the beta subunit of RNA polymerase, which is codified by the $r p o B$ gene, inhibiting the transcription process. Mutations at the $r p o B$ produce conformational enzymatic changes and, therefore, resistance. About $95 \%$ of the rifampicin-resistant isolated MT strains have mutations in a $69 \mathrm{bp}$ region of this gene ${ }^{13,19,20}$.

Several mutations, affecting one or more genes, have been found to be associated to isoniazide resistance; these include point mutations in genes such as the one that codifies the catalaseperoxidase enzyme ( $k a t G)$; the enoyl-ACP reductase, involved in the biosynthesis of mycolic acid (inhA); the alkyl hydroperoxide reductase, involved in cellular response to oxidative stress $(a h p C)$, or, with lower frequency, even the $\beta$-ketoacyl-ACP synthase (kas $A$ ). Mutations in the kat $G$ and $i n h A$ genes are found in $75-85 \%$ of $M$. tuberculosis isolates resistant to this drug ${ }^{20,21}$.

Pyrazinamide is a highly specific drug against $M$. tuberculosis, with no or minor effect against other Mycobacterium species but with a high level of intrinsic resistance observed. More than $70 \%$ of the $M$. tuberculosis strains resistant to pyrazinamide have mutations in the gene $p n c A$, which codifies a pyrazinamidase enzyme that converts the drug to its active form. On the other hand, there is no perfect correlation between loss of pyrazinamidase activity and pyrazinamide resistance; mycobacteria may be resistant to the drug in spite of having enzyme activity ${ }^{20,22}$. 
The genetic bases of ethambutol resistance are associated with modifications in the $\mathrm{embB}$ gene in $70 \%$ of the resistant isolated strains. Mutations in multiple codons have been found, resulting in two, three, or four amino acid changes in the EmbB protein. The most frequent, however, were found in codon 306 , a conserved methionine coding region ${ }^{20,23}$

In our study, we found no PCR-SSCP pattern that might correspond to a phenotype resistant to the main drugs used in MT treatment, except for one sample with a polymorphism in the $e m b B$ gene that could correspond to resistance to ethambutol. For diagnostic purposes, that genotypic profile would have to be confirmed, ideally by sequencing; however, that is beyond the scope of this study. Our aim was to evaluate the PCR-SSCP technique as a screening tool for detection of $M$. tuberculosis resistance and, as a consequence, to obtain a notion of the prevalence of resistant strains in our population; the existing data lack scientific evidence, being only empirically suspected by the physicians in the public health system. The low prevalence of genotypic alterations is probably due to the efficiency and seriousness with which TB treatment is performed in our region. Tuberculosis drugs, as well as laboratory tests, are given at no cost to the patients, and medication is given through health agents, who personally deliver the drug to the house or workplace of the patient and then wait to see if the medicine is appropriately taken. Adhesion to treatment is very high. Only those patients who demonstrate commitment and capacity to take the medicine in the appropriate manner who earn the trust of the health agents are allowed to take home doses sufficient for a few weeks and take the drugs by themselves. However, surveillance and monitoring by the health agents continue to the end of the treatment period.

The failure of our procedure to detect some mutations must be taken into account. The detection of isoniazide-resistant strains, for instance, is quite complex, due to the number of genes involved and of regions to be analyzed. It is well known that the prevalence of the described mutations that may confer isoniazide resistance can vary according to the geographic location of the isolates; studies with $M$. tuberculosis strains in Brazil have demonstrated a significant variation, from 50 to $80 \%$, depending on the region where the bacilli have been isolated. Mutations in the $k a t G$ gene are responsible for 58 to $68 \%$ of the resistant strains, while $32 \%$ of the mutations appear in the inh $A$ gene. Mutations in other sites, such as in the promoter region of the $a h p C$ gene, are less frequent but do exist ${ }^{10}$. One must also consider that these apparently high rates of resistance actually do not represent the global prevalence of mutants in our population. In Brazil, requests for culture and antibiotic susceptibility testing in the public health system are only allowed for patients with conventional treatment failure or immunosupressed ones, which obviously produces a bias in these studies.

Another point to be considered in our study is that some mutations may not be detected because of limitations of the method. It should be noted that the sensitivity of the method is inversely proportional to the size of the amplified fragment. Thus, the number of mutations detected decreases when fragments smaller than 150 to $200 \mathrm{bp}$ are analyzed. Also, depending on the polyacrylamide concentration, the temperature, $\mathrm{pH}$, or even the presence of additives, such as glycerol, the electrophoretic mobility, and the resolution may be affected ${ }^{24}$.

It is also noteworthy that it was not possible to amplify the DNA of the studied genes from every sample with a positive result by culture. One reasonable explanation for this is the sensitivity difference between PCR with primers directed at the mentioned genes and PCR developed for diagnostic purposes. Even the amplification of the IS6110 region of M. tuberculosis did not achieve the same sensitivity of culture for TB diagnosis. It is therefore expected that PCR designed to amplify regions of the genes where the mutations usually responsible for MT resistance are found would not be able to amplify the DNA of every positive sample.

Furthermore, as has already been demonstrated, in our population, samples from patients suspicious of having TB with a positive result by culture may actually be infected by nonM. tuberculosis species? ${ }^{7}$. The genetic diversity among the Mycobacterium species sequences may prevent the studied genes from being amplified in PCR-SSCP.

It has been reported that the prevalence of resistant $\mathrm{TB}$ has significantly increased in the last years and, according to the Brazilian Society of Pneumology and Thisiology, it is possible that 50 million people around the world may be infected with resistant M. tuberculosis. Therefore, there is an obvious need for the availability of rapid and accurate tests capable of detecting resistant MT in a certain population. Automated culture methods with liquid media and antibiotic susceptibility testing have been validated and are accepted, and may reduce the wait for results to 10-40 days for culture and more than 10 days for drug sensitivity ${ }^{5}$; however, the cost of these methods largely supplant the value of the tests received by laboratories in Brazil. Polymerase chain reaction-single-strand conformation polymorphism may contribute to filling in this gap, with the increasing availability of laboratories capable of performing molecular diagnosis across the country.

According to the $\mathrm{WHO}$, a prevalence of resistant bacilli higher than $2 \%$ has the inefficacy of the therapeutic scheme and the inefficiency of local TB control programs as principal causes. The prevalence of genotypic alterations indicated is only $0.01 \%$, which certainly does not represent an additional problem in local control of the disease. In some parts of Brazil, a large proportion of patients fail to follow the adequate treatment regime ${ }^{25}$. In any case, it is obviously necessary to maintain surveillance for the purpose of monitoring and detecting an eventual rise in MT resistance rates in our population. In spite of its limitations, PCR-SSCP constitutes an easy, reliable, and fast method in this context.

\section{CONFLICT OF INTEREST}

The authors declare that there is no conflict of interest.

\section{FINANCIAL SUPPORT}

Fundação de Amparo à Pesquisa e Inovação do Estado de Santa Catarina - FAPESC grant no. 14594/2005-7.

\section{REFERENCES}

1. Borella VR, Sato DN, Fonseca BAL. Problems in the standardization of the polymerase chain reaction for the diagnosis of pulmonary tuberculosis. Rev Saude Publica 1999; 33:281-286.

2. Ministério da Saúde. Tuberculose: guia de vigilância epidemiológica. Brasília: Ministério da Saúde; 2002.

3. Johnson R, Streicher EM, Louw GE, Warren RM, van Helden PD, Victor TC. Drug Resistance in Mycobacterium tuberculosis. Curr Issues Mol Biol 2006; 8:97-112. 
4. Castelo Filho A, Kritski AL, Barreto AW, Lemos ACM, Ruffino Netto A, Guimarães CA, et al. II Consenso Brasileiro de Tuberculose. J Bras Pneumol 2004; 30:S1-56.

5. Conde MB, Melo FAF, Marques AMC, Cardoso NC, Pinheiro VGF, Dalcin PTR, et al. III Brazilian Thoracic Association Guidelines on Tuberculosis. J Bras Pneumol 2009; 35:1018-1048.

6. Campinas LLSL, Ferrazoli L, Telles MAS, Matsumoto NF, Biagolini RAM, Ferraz SMP. Tuberculose, manual de orientação. São Paulo: Secretaria da Saúde. Divisão de Tuberculose; 2002.

7. Marchi AM, Juttel ID, Kawacubo EM, Dalmarco EM, Blatt SL, Cordova CMM. Evaluation of methods for detection and identification of Mycobacterium species in patients suspected of having pulmonary tuberculosis. Brazilian Journal of Microbiology 2008; 39:613-618.

8. Eisennach KD, Cave MD, Crawford JT. PCR detection of Mycobacterium tuberculosis. In: Pershing DH, Smith TF, Tenover FC, White TJ, editors. Diagnostic Molecular Microbiology, Principles and Applications. Rochester: Mayo Foundation; 1993. p. 191-196.

9. Kim BJ, Kim SY, Park BH, Lyu MA, Park IK, Bai GH, et al. Mutations in the rpoB gene of Mycobacterium tuberculosis that interfere with PCR-single-strand conformation polymorphism analysis for rifampin susceptibility testing. J Clin Microbiol 1997; 35:492-494.

10. Chan RCY, Hui M, Chan EWC, Au TK, Chin ML, Yip CK, et al. Genetic and phenotypic characterization of drug-resistant Mycobacterium tuberculosis isolates in Hong Kong. Journal of Antimicrobial Chemotherapy 2007; 59:866-873.

11. SambrookJ, Russel D. Molecular cloning: a laboratory manual, $3^{\text {rd }}$ ed. New York: Cold Spring Harbor Laboratory; 2001.

12. Barreira D, Grangeiro A. Evaluation of tuberculosis control strategies in Brazil. Rev Saude Publica 2007; 41:4-8.

13. Carvalho WS, Miranda SS, Pesquero JL, Gomes MA. Diagnóstico de resistência do Mycobacterium tuberculosis à rifampicina utilizando-se da reação em cadeia da polimerase. Rev Bras Ciênc Farm 2007; 43:31-38.

14. Maciel ELN, Vieira RCA, Milani EC, Brasil M, Fregona G, Dietze R. Community health workers and tuberculosis control: knowledge and perceptions. Cad Saude Publica 2008; 24:1377-1386.

15. Natal S. Emergência da resistência às drogas. Bol Pneumol Sanit 2002; 10:57-70.

16. Clark-Curtiss JE, Haydel SE. Molecular Genetics of Mycobacterium Tuberculosis pathogenesis. Ann Rev Microbiol 2003; 57:517-549.

17. Barroso EC, Mota RMS, Santos RO, Sousa ALO, Barroso JB, Rodrigues JLN. Risk factors for acquired multidrug-resistant tuberculosis. J Bras Pneumol 2003; 29:89-97.

18. Dalcomo MP, Andrade MK, Picon PD. Multiresistant tuberculosis in Brazil: history and control. Cad Saude Publica 2007; 41:34-42.

19. Telenti A, Philipp WJ, Sreevatsan S. The emb operon, a gene cluster of Mycobacterium tuberculosis involved in resistance to ethambutol. Nature Med 1997; 3:567-570.

20. Rossetti MLR, Valim ARM, Silva MSN, Rodrigues VS. Resistant tuberculosis: a molecular review. Cad Saude Publica 2002; 36:525-532.

21. Musser JM, Kapur V, Williams DL, Kreiswirth BN, van Soolingen D, van Embdem JDA. Characterization of the catalase-peroxidase gene ( $k a t G)$ and $\operatorname{inh} A$ locus in isoniazid-resistance and susceptible strains of Mycobacterium tuberculosis by automated DNA sequencing: restricted array of mutations associated with drug resistance. J Infect Dis 1996; 173:196-202.

22. Sreevatsan S, Pan X, Zhan Y, Kreiswirth BN, Musser JM. Mutations associated with pyrazinamide resistance in pncA of Mycobacterium tuberculosis complex organisms. Antimicrob Agents Chemoter 1997; 41:636-640.

23. Telenti A, Honore N, Bernasconi C, March J, Ortega A, Heym B, et al. Genotypic assessment of isoniazid and rifampin resistance in Mycobacterium tuberculosis: a blind study at reference laboratory level. J Clin Microbiol 1995; 35:719-723.

24. Salazar LA, Hirata MH, Hirata RDC. Increasing the Sensitivity of SingleStrand Conformation Polymorphism Analysis of the LDLR Gene Mutations in Brazilian Patients with Familial Hypercholesterolemia. Clin Chem Lab Med 2002;40:441-445.

25. Pelly T, Moore DAJ, Gilman R, Evans C. Recent tuberculosis advances in Latin America. Curr Opin Infect Dis 2004; 17:397-403. 